\title{
Strategi Pengembangan Mempawah Mangrove Center (MMP) Kabupaten Mempawah Hilir
}

\author{
Erni Yuniarti ${ }^{\text {a }}$ \\ a Jurusan Perencanaan Wilayah dan Kota, Universitas Tanjungpura Pontianak, Indonesia \\ E-mail Korespondensi:erniyuniarti1978@gmail.com
}

\begin{abstract}
Mempawah Mangrove Center terletak di Jalan Gusti Sulung Lelanang, Desa Pasir, Kecamatan Mempawah Hilir. Keunggulan yang dimiliki adalah hutan mangrove dengan spesifikasi kegiatan wisata berupa wisata alam. Luas untuk peruntukan wisata adalah 4 Ha dan luas hutan mangrove-nya dilihat dari perekaman Citra Google Earth adalah $51 \mathrm{Ha}$. MMP merupakan kawasan mangrove pertama yang dijadikan sebagai kawasan wisata alam, sehingga disebut sebagai penggerak berkembangnya wisata mangrove di Kalimantan Barat. Namun, masih terdapat berbagai permasalahan yang dihadapi oleh MMP antara lain, aksi vandalisme, seperti mencoret, mengukir, dan mematahkan pohon mangrove, serta permasalahan kebersihan lingkungan seperti sampah baik yang dihasilkan oleh wisatawan maupun sampah pengaruh pasang surut air laut. Tujuan penelitian adalah merumuskan strategi pengembangan Mempawah Mangrove Center. Pendekatan penelitian yang digunakan adalah penelitian kualitatif. Teknik pengumpulan data melalui wawancara, observasi, dan studi literatur. Berdasarkan hasil analisis SWOT diperoleh bahwa MMP berada pada Kuadran I atau strategi S-O artinya posisi yang sangat menguntungkan. Strategi yang harus diterapkan dalam kondisi ini adalah strategi agresif dengan memanfaatkan kekuatan dan peluang yang ada dalam pengembangan kawasan wisata MMP. Adapun strategi pengembangan yang dapat dilakukan antara lain memperluas promosi wisata, meningkatkan kapasitas pengelola wisata, membentuk regulasi, membangun spot pendukung wisata, dan menjalin hubungan dengan kemitraan.
\end{abstract}

Keywords: kawasan wisata, mempawah mangrove center, strategi pengembangan

Abstract: Mempawah Mangrove Center is located on Jalan Gusti Sulung Lelanang, Pasir Village, Mempawah Hilir District. The advantages are mangrove forests with specifications of tourist activities in the form of natural tourism. The area for tourism purposes is $4 \mathrm{Ha}$ and the area of mangrove forest seen from the recording of Google Earth Imagery is $51 \mathrm{Ha}$. MMP is the first mangrove area that is used as a natural tourism area, so it is referred to as the driver of mangrove tourism development in West Kalimantan. However, there are still various problems faced by $M M P$, among others, acts of vandalism, such as scribbling, carving, and breaking mangrove trees, as well as environmental hygiene problems such as garbage both produced by tourists and garbage influenced by the tides of the sea. The purpose of the research is to formulate the development strategy of Mempawah Mangrove Center. The research approach used is qualitative research. Data collection techniques through interviews, observations, and literature studies. Based on the results of swot analysis obtained that MMP is in Quadrant I or S-O strategy means a very profitable position. The strategy that must be applied in these conditions is an aggressive strategy by utilizing the strengths and opportunities that exist in the development of MMP tourist areas. The development strategies that can be done include expanding tourism promotion, increasing the capacity of tour managers, establishing regulations, building tourist support spots, and establishing relationships with partnerships.

Keywords: tourist areas, mempawah mangrove center, development strategy

How to cite (APA 6th Style):

Yuniarti, Erni. (2021). Strategi Pengembangan Mempawah Mangrove Center (MMP) Kabupaten Mempawah Hilir. 2(1), 50-58. doi: 10.26418/uniplan.v2i1.45900

\section{PENDAHULUAN}

Kabupaten Mempawah merupakan daerah pesisir yang memiliki kekayaan alam berlimpah berupa 
terumbu karang, mangrove, pantai, sungai, hingga keanekaragaman ekologi biotik. Satu diantara destinasi wisata yang telah berkembang di Kabupaten Mempawah adalah Mempawah Mangrove Park (MMP). Terletak di Desa Pasir, Kecamatan Mempawah Hilir dan dikelola langsung oleh Kelompok Sadar Wisata (Pokdarwis) Desa Pasir. MMP merupakan wisata alam yang termasuk dalam kawasan strategis kepariwisataan di Kabupaten Mempawah dari segi kepentingan fungsi dan daya dukung lingkungan (RIPPDA Kabupaten Mempawah Tahun 2016).

Perkembangan MMP berawal dari tersedianya jalur tracking sepanjang 350 meter di tahun 2016. Pada tahun 2018, MMP telah memiliki banyak fasilitas penunjang, objek wisata tambahan dan penambahan panjang mangrove tracking menjadi 588 meter. MMP juga memiliki daya tarik alam berupa kombinasi hamparan hutan mangrove dan laut, serta matahari terbenam. MMP merupakan lokasi mangrove pertama yang dijadikan sebagai kawasan wisata alam, maka disebut sebagai penggerak pertama berkembangnya wisata mangrove di Kalimantan Barat. MMP juga menawarkan atraksi berupa penanaman bibit mangrove sebagai kegiatan unggulannya.

Berbagai potensi tersebut telah banyak menarik minat wisatawan untuk berkunjung. Ketua Pokdarwis Desa Pasir menyatakan bahwa, kunjungan meningkat sebesar 4,67\% dari tahun 2016 dengan jumlah wisatawan yang berkunjung adalah 12.200 orang. Jumlah kunjungan wisatawan pada tahun 2018 kembali mengalami peningkatan sebesar 0,56\% dari tahun sebelumnya dengan jumlah wisatawan adalah 108.072 (Marjayanti, 2020). Jumlah kunjungan wisatawan di MMP diprediksi akan terus mengalami peningkatan. Maka, terjadi pula peningkatan aktivitas wisata yang dapat menimbulkan permasalahan lingkungan. Ketua Pokdarwis Desa Pasir menyatakan, dampak yang paling terasa saat jumlah kunjungan meningkat adalah peningkatan sampah yang berserakan. Hal ini menyebabkan lingkungan objek wisata menjadi kotor dan berakibat mengganggu pertumbuhan bibit mangrove. Belum lagi vandalisme yang dilakukan wisatawan berupa mencoret, mengukir, mematahkan, dan merusak setiap bagian pohon mangrove baik secara sadar maupun tidak sadar. Tingkat kenyamanan wisatawan juga akan berkurang apabila terjadi kepadatan yang tinggi (Gunn, 1994 dalam Muhamad, 2013). Selain itu, MMP merupakan kawasan wisata yang berbatasan langsung dengan laut, sehingga sangat dipengaruhi oleh pasang surutnya air laut. Pasang air laut juga juga sering membawa sampah dari arah laut yang kemudian mengotori kawasan ekowisata.

Oleh karena itu, merujuk pada potensi dan permasalahan MMP perlu dilakukan perumusan strategi pengembangan MMP sehingga nantinya dapat meningkatkan perkembangan kualitas kawasan wisata yang tidak hanya berpengaruh terhadap peningkatan perekonomian lokal, namun juga lingkungan kawasan.

\section{DATA DAN METODE}

\subsection{Pariwisata}

Pariwisata merupakan suatu kegiatan yang berhubungan dengan wisata dan melibatkan banyak orang, dimana kegiatan pariwisata erat hubungannya dengan keinginan manusia untuk rekreasi. Ada 3 komponen pariwisata yaitu: asal (tempat tinggal wisatawan), perjalanan (sarana menuju tujuan dan kembali ke tempat asal), dan tujuan (tempat yang dikunjungi nwisatawan) (Soekadijo 2000, Wibowo 2001). Orang yang melakukan kegiatan pariwisata disebut wisatawan. Setiap wisatawan merencanakan suatu perjalanan ke sutau tempat, disebabkan karena adanya suatu maksud, tujuan, atau motivasi tertentu. Motivasi perjalanan tersebut ditimbulkan oleh adanya daya tarik wisata. Wisatawan sebagai subjek pariwisata juga melakukan perjalan wisata dengan berbagai macam jenis ditinjau dari jumlahnya adalah (Suwantoro, 2004 dalam Suryadana, 2013):

a. Individual Tour, yaitu suatu perjalanan wisata yang dilakukan oleh satu orang atau sepasang kekasih.

b. Family Group, disebut juga kelompok dimana suatu perjalanan wisata dilakukan oleh segerombongan keluarga yang masih mempunyai hubungan kekerabatan atau kekeluargaan satu sama lain.

c. Group Tour, yaitu perjalan wisata yang dilakukan bersama-sama dalam satu rombongan dengan dipimpin oleh seorang yang bertanggung jawab atas keselamatan dan kebutuhan seluruh anggota, terdiri dari 8 orang atau lebih. 


\subsection{Pengembangan Kawasan Mangrove}

Hutan mangrove merupakan salah satu tipe hutan hujan tropis yang terdapat di sepanjang garis pantai perairan tropis dan subtropis serta memiliki ciri yang sangat unik. Hutan mangrove dikenal pula dengan istilah tidal forest, coastal woodland, vloedbosschen, dan hutan payau. Penggunaan istilah hutan mangrove sebagai hutan bakau dianggap kurang tepat karena bakau merupakan satu diantara jenis tumbuhan yang terdapat dalam hutan mangrove. Hutan mangrove memiliki sifat yang unik dan tidak sama seperti jenis hutan tropis lainnya karena berada pada peralihan ekosistem daratan dan lautan (Wibisono, 2004). Pengelolaan ekosistem mangrove merupakan suatu upaya untuk memelihara, melindungi, dan merehabilitasi agar pemanfaatan terhadap ekosistem ini dapat berkelanjutan. Tujuan pengelolaan ekosistem mangrove adalah mencapai manfaat yang sebesar-besarnya dari hutan secara serbaguna dan lestari (Kenneth, 1979 dalam Schaduw, 2010).

Pengelolaan dan pengembangan ekosistem mangrove untuk daerah pesisir dapat dijumpai pada hampir seluruh kawasan pantai yang memiliki ekosistem mangrove. Melihat beragamnya manfaat mangrove, maka tingkat dan laju perekonomian pedesaan yang berada di kawasan pesisir seringkali sangat bergantung pada habitat mangrove yang ada di sekitarnya. Mangrove memiliki peranan penting dalam melindungi pantai dari gelombang, angin dan badai. Tegakan mangrove dapat melindungi pemukiman, bangunan dan pertanian dari angin kencang atau intrusi air laut. Mangrove juga terbukti memainkan peran penting dalam melindungi pesisir dari gempuran badai. Kemampuan mangrove untuk mengembangkan wilayahnya ke arah laut merupakan salah satu peran penting mangrove dalam pembentukan lahan baru (Noor, dkk., 2006).

\subsection{Metode Analisis}

Penelitian ini menggunakan pendekatan kualitatif. Populasi dalam penelitian ini adalah wisatawan dan pengelola ekowisata MMP. Pemilihan narasumber pada penelitian ini menggunakan purposive sampling karena narasumber yang dijadikan sampel berdasarkan pada pakar yang dipilih secara sengaja karena memiliki kepakaran sesuai dengan bidang yang dikaji (Bungin 2011, Morissan 2015). Pengumpulan data adalah proses memperoleh dan mengukur berbagai informasi tentang variabel yang diteliti (Asra, 2015). Pengumpulan data terdiri dari dua kategori yaitu pengumpulan data primer dengan observasi, wawancara dan pengumpulan data sekunder dengan studi literatur. Penelitian ini menggunakan teknik analisis deskriptif kualitatif dan analisis SWOT. Pengumpulan data dalam laporan ini diklasifikasikan dalam faktor internal dan faktor eksternal Kampung Wisata Tenun Khatulistiwa. Faktor internal yaitu kekuatan (strengths) dan kelemahan (weakness). Faktor eksternal yaitu peluang (opportunity) dan ancaman (threats).

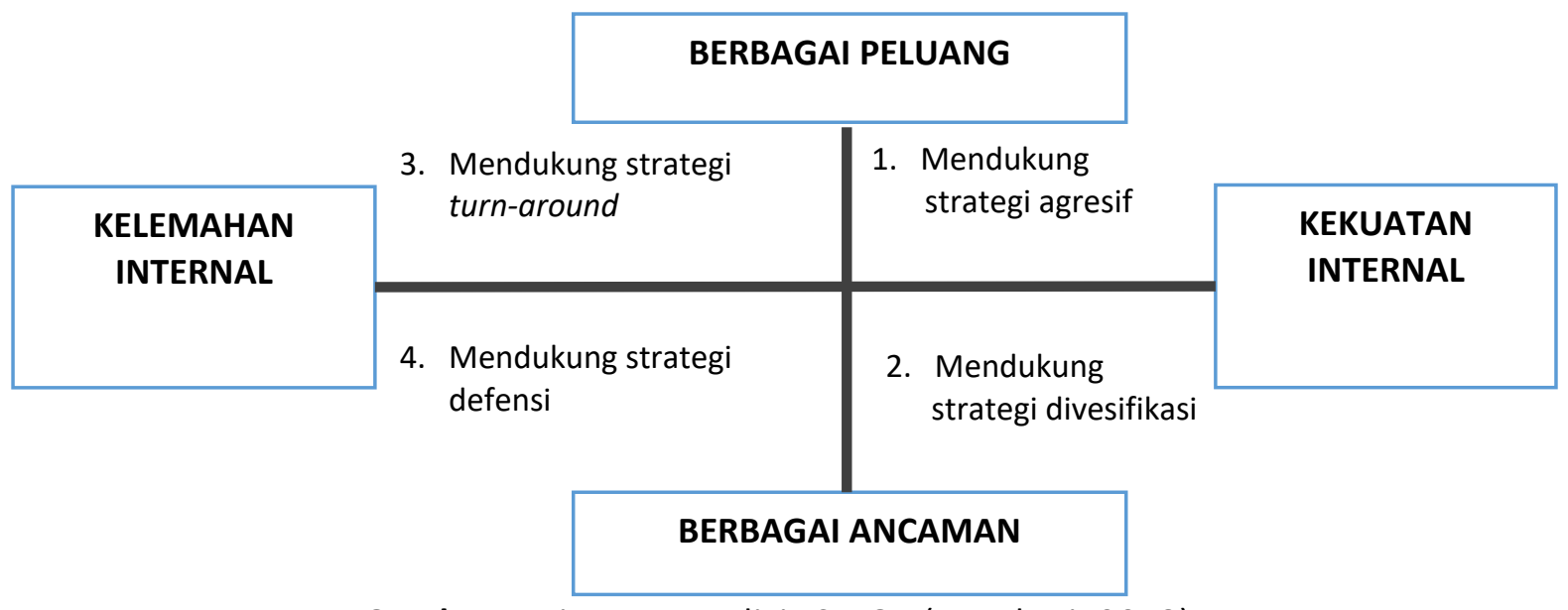

Gambar 1 Diagram Analisis SWOT (Rangkuti, 2018)

Berdasarkan kuadran SWOT terdapat 4 kuadran antara lain,

- Kuadran I, merupakan posisi yang sangat menguntungkan. Mempawah Mangrove Center ini memiliki peluang dan kekuatan sehingga dapat memanfaatkan peluang yang ada. Strategi kebijakan 
pertumbuhan yang agresif.

- Kuadran II, meskipun menghadapi berbagai ancaman, Mempawah Mangrove Center masih memiliki kekuatan dari segi internal. Strategi diversifikasi (produk/pasar).

- Kuadran III, Mempawah Mangrove Center menghadapi peluang besar, tetapi disisi lain ia menghadapi beberapa kendala atau kelemahan internal.

- Kuadran IV, merupakan kondisi yang sangat tidak menguntungkan, Mempawah Mangrove Center menghadapi berbagai ancaman dan kelemahan.

\section{HASIL DAN PEMBAHASAN}

Mempawah Mangrove Park (MMP) merupakan satu diantara objek wisata alam yang terdapat di Kabupaten Mempawah. Keunggulan yang dimiliki adalah hutan mangrove dengan spesifikasi kegiatan wisata berupa wisata alam. Berdiri sejak tahun 2016, MMP dikelola langsung oleh Pokdarwis Desa Pasir, di bawah naungan Bidang Pariwisata dan Kebudayaan yang menjadi bagian dari Dinas Pendidikan, Pemuda, Olahraga dan Pariwisata Kabupaten Mempawah. MMP berlokasi di Jalan Gusti Sulung Lelanang, Desa Pasir, Kecamatan Mempawah Hilir. Luas untuk peruntukan wisata adalah $4 \mathrm{Ha}$ dan luas hutan mangrove-nya dilihat dari perekaman Citra Google Earth adalah 51 Ha memanjang di pesisir Kawasan Perkotaan Mempawah.

\subsection{Identifikasi Mempawah Mangrove Center}

Daya Tarik Wisata : Terdapat 3 kriteria daya tarik yang dapat dinikmati di MMP, yaitu daya tarik yang dapat dilihat (something to see), aktivitas yang dapat dilakukan (something to do), dan sesuatu yang dapat dibeli (something to buy). Potensi atau daya tarik yang khas sangat menentukan tingkat kunjungan pada kawasan tertentu (Yuniarti, dkk., 2018)

Tabel 1 Daya Tarik Wisata MMP (Analisis, 2020)

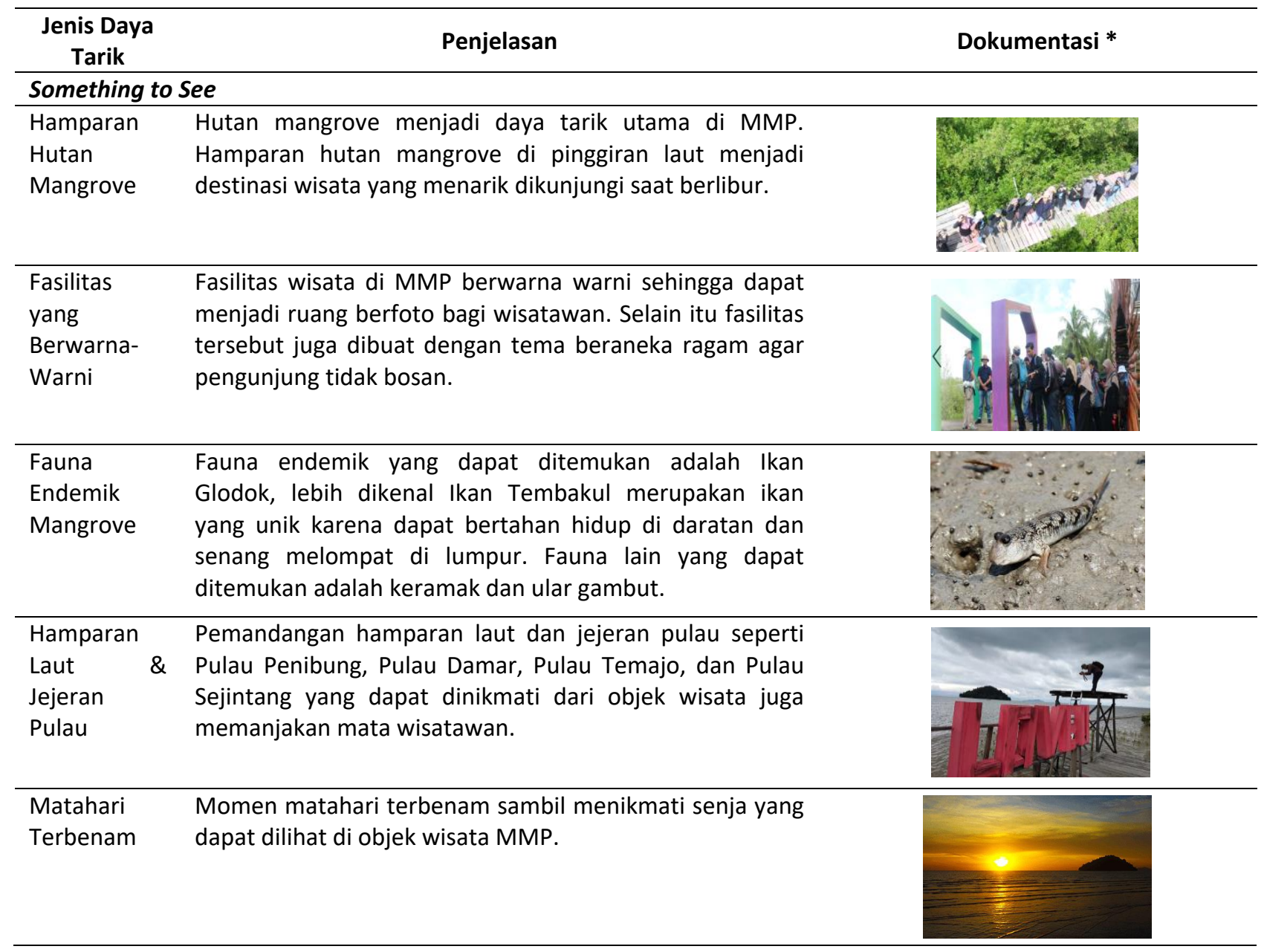




\begin{tabular}{lll}
\hline $\begin{array}{l}\text { Jenis Daya } \\
\text { Tarik }\end{array}$ & \multicolumn{1}{c}{ Penjelasan } & Dokumentasi * \\
\hline Something To Do & Tracking berupa jalan santai mengelilingi objek wisata \\
sambil menikmati hutan mangrove pada jalur tracking. \\
Jalur tracking di MMP yang dibuat bercabang-cabang, \\
& $\begin{array}{l}\text { berkelok, dan naik turun membuat kegiatan ini } \\
\text { menyenangkan. }\end{array}$ & \\
& Tersedia 2 jenis fasilitas yang dapat wisatawan pilih untuk \\
& duduk santai, yaitu area duduk dan pendopo. Area duduk \\
& persifat terbuka tanpa atap, sedangkan pendopo berupa & \\
\hline puduk santai beratap rumbia.
\end{tabular}

\begin{tabular}{ll}
\hline Menanam & MMP juga menawarkan kegiatan menanam bibit \\
Mangrove & mangrove yang rutin dilakukan setiap 3 bulan sekali dan \\
& dapat diikuti oleh wisatawan secara umum. Dalam \\
& kegiatan tertentu dan hari-hari peringatan tertentu, MMP \\
& juga mengadakan agenda menanam bibit mangrove \\
& diluar dari jadwal rutinnya dan dapat pula diikuti oleh \\
& umum. Di hari biasa wisatawan juga dapat melakukan \\
& kegiatan penanaman bibit namun dengan rombongan \\
& minimal 10 orang.
\end{tabular}

\begin{tabular}{ll}
\hline Bermain & Taman bermain yang tersedia memang masih minim, \\
& namun karena terletak di area yang luas maka anak-anak \\
& juga dapat berlari-lari dan memainkan permainan \\
& tradisional yang tersedia di area tersebut. Taman bermain \\
& juga dikelilingi pohon yang teduh.
\end{tabular}

Tur Studi Wisatawan dapat membuat dan melakukan kegiatan

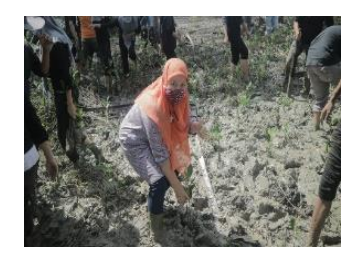
belajar mengajar untuk kegiatan yang bersifat tur studi
karena telah tersedia beberapa fasilitas untuk berdiskusi
belajar mengajar untuk kegiatan yang bersifat tur studi
karena telah tersedia beberapa fasilitas untuk berdiskusi dan belajar, seperti perpustakaan atau mangrove house. dan belajar, seperti perpustakaan atau mangrove house.

\begin{tabular}{ll}
\hline Berfoto & Wisatawan dapat melakukan swafoto ataupun berfoto \\
& bersama kerabat dan teman. Tema atau konsep spot-spot \\
& foto yang disediakan tidak monoton, sehingga wisatawan \\
& dapat dengan bebas berkreasi dalam mengambil foto.
\end{tabular}

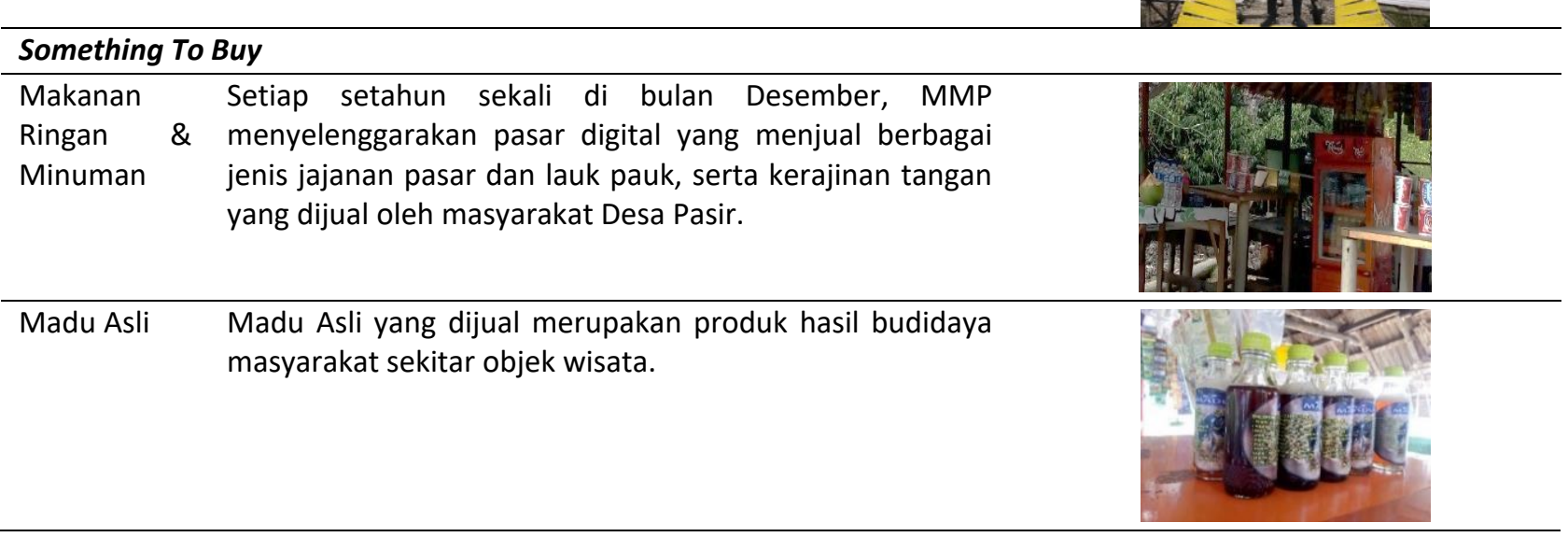


Fasilitas Wisata: terdiri dari jalur tracking, galeri, mangrove information centre, spot-spot foto, area duduk, pendopo, mangrove house, mangrove reading house, mangrove nursery, taman bermain anak, menara pandang, dan koningsplein

Fasilitas Penunjang Wisata: terdiri dari loket tiket, toilet umum, kantin, musala, parkir, tempat sampah, papan informasi, gapura, rambu penunjuk arah, dan dermaga.

Utilitas: Sumber air bersih di MMP berasal dari PDAM Kabupaten Mempawah digunakan untuk mengairi toilet umum, berbilas setelah melakukan penanaman bibit mangrove di dalam lumpur, berwudhu, dan mengairi semai dan bibit mangrove di mangrove nursery. Sistem pengelolaan sampah di MMP belum terpisah antara sampah organik dan anorganik karena menggunakan metode pembakaran sampah.

Aksesibilitas : Jalur utama masuk ke objek wisata MMP adalah Jalan Gusti Sulung Lelanang yang berfungsi sebagai jalan arteri di Kecamatan Mempawah Hilir. Jalan tersebut memiliki status sebagai Jalan Nasional Provinsi Kalimantan Barat yang menghubungkan beberapa kecamatan di Kabupaten Mempawah dan jalan penghubung Kabupaten Mempawah dengan kabupaten lainnya di Kalimantan Barat.

\subsection{Analisis SWOT Mempawah Mangrove Center}

Strategi pengembangan Mempawah Mangrove Center dilakukan menggunakan Analisis SWOT yang membandingkan antara faktor eksternal peluang dan ancaman dengan faktor internal kekuatan dan kelemahan. IFAS merupakan faktor-faktor strategis yang berasal dari kondisi dalam Mempawah Mangrove Park (MMP) yang mempengaruhi kegiatan pengembangan wisata.

\subsubsection{IFAS (Internal Strategic Factor Analysis)}

IFAS merupakan faktor-faktor strategis yang berasal dari kondisi dalam Mempawah Mangrove Park (MMP) yang mempengaruhi kegiatan pengembangan wisata. IFAS terdiri dari kekuatan (strenght) dan kelemahan (weakness). Kekuatan merupakan faktor yang memiliki nilai positif, sedangkan kelemahan merupakan faktor yang memiliki nilai negatif. Kedua faktor tersebut diberi bobot dan rating untuk mengetahui skor setiap faktor yang ada.

Tabel 3 Faktor Strategis Internal (IFAS) Dalam Pengembangan MMP (Analisis, 2020)

\begin{tabular}{|c|c|c|c|c|}
\hline Kode & Faktor Internal & Bobot & Rating & Skor \\
\hline \multicolumn{5}{|c|}{ Kekuatan (strenght) } \\
\hline S1 & Lokasi kawasan wisata yang strategis. & 0,15 & 4,00 & 0,62 \\
\hline S2 & Keindahan dan kekayaan alam menjadi daya tarik wisata. & 0,15 & 4,00 & 0,62 \\
\hline S3 & Konsep fasilitas yang tidak monoton. & 0,12 & 3,00 & 0,35 \\
\hline S4 & Tersedianya fasilitas wisata dan fasilitas penunjang dengan lengkap. & 0,12 & 3,00 & 0,35 \\
\hline S5 & Aksesibilitas menuju lokasi MMP memadai. & 0,12 & 3,00 & 0,35 \\
\hline \multicolumn{2}{|r|}{ Sub Total Kekuatan } & 0,65 & 17,00 & 2,27 \\
\hline \multicolumn{5}{|c|}{ Kelemahan (Weakness) } \\
\hline W1 & Kayu mangrove beresiko membahayakan pengunjung. & 0,08 & 2,00 & 0,15 \\
\hline W2 & Penggunaan bahan bangunan kayu memerlukan perawatan ekstra. & 0,04 & 1,00 & 0,04 \\
\hline W3 & Pengelolaan sampah belum memadai. & 0,08 & 2,00 & 0,15 \\
\hline W4 & $\begin{array}{l}\text { Belum adanya keterkaitan dengan objek wisata lain di Kawasan } \\
\text { Perkotaan Mempawah. }\end{array}$ & 0,08 & 2,00 & 0,15 \\
\hline W5 & Lapangan parkir bukan lahan MMP. & 0,08 & 2,00 & 0,15 \\
\hline \multicolumn{2}{|r|}{ Sub Total Kelemahan } & 0,35 & 9,00 & 0,65 \\
\hline \multicolumn{2}{|r|}{ Total Skor } & 1,00 & 26,00 & 2,92 \\
\hline
\end{tabular}

Nilai total skor faktor internal pengembangan wisata MMP adalah 2,92 (di atas 2,5) sehingga dapat 
dikatakan bahwa pengelola MMP mampu memanfaatkan kekuatan dengan meminimalkan kelemahan. Faktor kekuatan terbesar dengan skor 0,62 yaitu lokasi strategis dan keindahan serta kekayaan alam yang dimiliki MMP. Faktor kelemahan di kawasan MMP dengan skor terbesar 0,15 terdiri dari 4 faktor.

\subsubsection{EFAS (Eksternal Strategic Factor Analysis)}

Matriks EFAS digunakan untuk mengetahui kondisi eksternal yang dihadapi oleh MMP. Pengumpulan data mengenai faktor eksternal yang meliputi faktor peluang dan ancaman yang dimiliki oleh kawasan MMP diperoleh dari hasil observasi dan diskusi dengan beberapa stakeholders. Nilai total rata-rata skor faktor eksternal pengembangan wilayah MMP berdasarkan tabel di atas, diketahui adalah sebesar 2,63 (di atas 2,5) sehingga dapat dikatakan bahwa pengelola MMP mampu memanfaatkan peluang yang ada serta mampu meminimalkan ancaman. Berdasarkan matriks EFAS di atas, peluang terbesar ada satu kriteria dengan skor 0,46 yaitu Keberadaan Pelabuhan Kijing sebagai jalur konektifitas tingkat lokal, regional, dan Internasional. Tabel di atas juga menunjukkan nilai skor faktor ancaman di kawasan MMP. Ancaman terbesar dengan skor 0,23 yaitu degradasi dan ancaman lingkungan terhadap kawasan MMP.

Tabel 3 Faktor Strategis Eksternal (EFAS) Dalam Pengembangan MMP (Analisis, 2020)

\begin{tabular}{|c|c|c|c|c|}
\hline Kode & Faktor Eksternal & & Rating & Skor \\
\hline \multicolumn{5}{|c|}{ Peluang (Opportunity) } \\
\hline 01 & $\begin{array}{l}\text { Keberadaan Pelabuhan Kijing sebagai jalur konektifitas tingkat lokal, } \\
\text { regional, dan Internasional }\end{array}$ & 0,11 & 4 & 0,46 \\
\hline 02 & $\begin{array}{l}\text { Adanya dukungan kebijakan pemerintah daerah dalam mengembangkan } \\
\text { MMP. }\end{array}$ & 0,11 & 3 & 0,34 \\
\hline 03 & Adanya tren pariwisata unggulan berbasis wisata alam. & 0,09 & 3 & 0,26 \\
\hline 04 & Peningkatan jumlah pengunjung MMP setiap tahunnya. & 0,09 & 3 & 0,26 \\
\hline 05 & Masifnya penyebarluasan informasi dan promosi secara online & 0,11 & 4 & 0,46 \\
\hline \multicolumn{2}{|r|}{ Sub Total Peluang } & 0,51 & 17 & 1,77 \\
\hline \multicolumn{5}{|c|}{ Ancaman (Threats) } \\
\hline T1 & Alih fungsi lahan hutan mangrove. & 0,09 & 2 & 0,17 \\
\hline T2 & Adanya pelonjakan jumlah pengunjung melebihi daya tampung & 0,11 & 1 & 0,11 \\
\hline T3 & Persaingan dengan objek wisata sejenis dengan daerah lain. & 0,09 & 2 & 0,17 \\
\hline T4 & Degradasi dan ancaman lingkungan terhadap kawasan MMP. & 0,11 & 2 & 0,23 \\
\hline T5 & $\begin{array}{l}\text { Terjadinya konflik kewenangan dalam pengelolaan kegiatan ekowisata di } \\
\text { kawasan konservasi. }\end{array}$ & 0,09 & 2 & 0,17 \\
\hline \multicolumn{2}{|r|}{ Sub Total Ancaman } & 0,49 & 9 & 0,86 \\
\hline \multicolumn{2}{|r|}{ Total Skor } & 1,00 & 26 & 2,63 \\
\hline
\end{tabular}

\subsubsection{Matriks Grand Strategy}

Berdasarkan hasil analisis faktor internal dan faktor eksternal menunjukkan bahwa total nilai skor dari masing-masing faktor dapat dirinci sebagai berikut:

Faktor kekuatan $=2,27$

Faktor kelemahan $=0,65$

Faktor peluang $=1,77$

Faktor ancaman $=0,86$
Penentuan koordinat diperoleh dari:

Skor total kekuatan - Skor total kelemahan $=2,27-0,65=1,62$

Skor total peluang - Skor total ancaman

$=1,77-0,86=0,91$

Maka titik koordinat terletak pada: $(0,91 ; 1,62)$ 


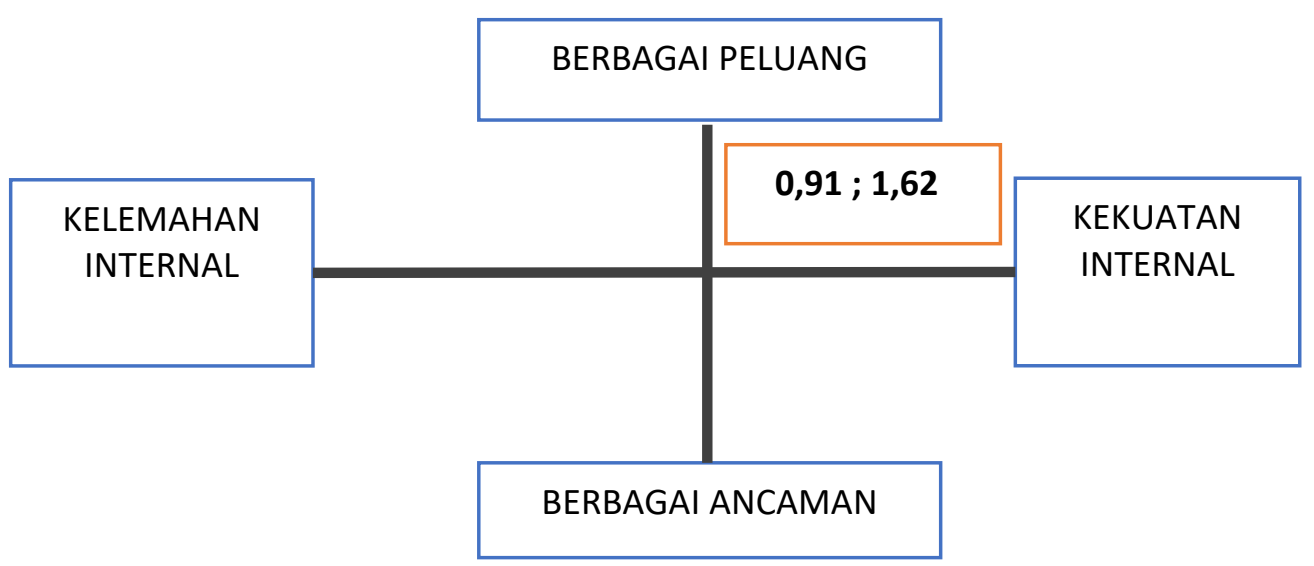

Gambar 2 Matriks Grand Strategy MMP (Analisis, 2020)

Mempawah Mangrove Park (MMP) berada pada Kuadran I artinya posisi yang sangat menguntungkan. Strategi yang harus diterapkan dalam kondisi ini adalah strategi agresif dengan memanfaatkan kekuatan dan peluang yang ada dalam pengembangan kawasan wisata MMP. Hasil analisis strategi pengembangan dengan menggunakan analisis SWOT diperoleh strategi pengembangan Mempawah Mangrove Center dapat dirumuskan sebagai berikut,

1. Memperluas jaringan promosi

- Meningkatkan promosi wisata dengan memanfaatkan media online

2. Meningkatkan kualitas sumber daya manusia pengelola Mempawah Mangrove Center

- Penguatan pengelola MMP dalam manajemen wisata

- Peningkatan partisipasi masyarakat dalam pengelolaan MMP

3. Membentuk regulasi MMP

- Penguatan regulasi tata guna lahan MMP

- Membuat peta pembagian zona lokasi wisata MMP

4. Membangun spot pendukung wisata

- Menambah fasilitas wisata berupa eco outbound dengan menyediakan pemandu khusus

- Menyediakan lahan parkir khusus lokasi wisata MMP.

- Pemisahan sampah organik dan nonorganik, serta pemanfaatan sampah sebagai bahan karya seni yang dapat dijual.

- Melakukan pembaharuan bahan bangunan fasilitas wisata yang ramah lingkungan dan aman bagi wisatawan

- Pembuatan pagar pembatas pada jalur tracking dan pengadaan papan informasi.

- Perawatan bangunan secara berkala.

5. Menjalin hubungan kemitraan

- Kerja sama dengan lembaga terkait pariwisata untuk kegiatan pengembangan MMP.

- Menjalin kerjasama dengan wisata di Kawasan Perkotaan Mempawah

- Menyediakan program tour wisata di Kawasan Perkotaan Mempawah.

- Mengadakan event tahunan yang mengundang komunitas, organisasi lingkungan, dan masyarakat umum

\section{KESIMPULAN}

Keunggulan yang dimiliki Mempawah Mangrove Park (MMP) adalah hutan mangrove dengan spesifikasi kegiatan wisata berupa wisata alam. MMP berlokasi di Jalan Gusti Sulung Lelanang, Desa Pasir, Kecamatan Mempawah Hilir. Daya tarik yang terdapat di MMP antara lain, hamparan hutan mangrove, fauna endemik mangrove, fasilitas warna-warni, hamparan laut dan jejeran pulau, serta pemandangan matahari terbenam. Namun dalam pengelolaannya, MMP masih dihadapi berbagai permasalahan antara lain kayu mangrove 
beresiko membahayakan pengunjung, selain itu penggunaan bahan bangunan kayu memerlukan perawatan ekstra. Dalam hal pengelolaan sampah, masih belum memadai dan juga belum didukung penyediaan lapangan parkir. Belum adanya keterkaitan dengan objek wisata lain di Kawasan Perkotaan Mempawah.

Rumusan SWOT strategi pengembangan MMP berada pada Kuadran I artinya posisi yang sangat menguntungkan. Strategi yang harus diterapkan dalam kondisi ini adalah strategi agresif dengan memanfaatkan kekuatan dan peluang yang ada dalam pengembangan kawasan wisata MMP. Terdapat tiga rumusan strategi pengembangan MMP sebagai wisata alam di Kawasan Perkotaan Mempawah yaitu (1) Meningkatkan promosi wisata dengan memanfaatkan media online (2) Meningkatkan kualitas sumber daya manusia pengelola Mempawah Mangrove Center (3) Membentuk regulasi MMP (4) Membangun spot pendukung wisata (5) Menjalin hubungan kemitraan misalnya dengan mengadakan event tahunan.

\section{DAFTAR PUSTAKA}

Asra, A., Irawan, P. B., Purwanto, A.(2015). Metode Penelitian Survei. Bogor. IN Media

Bungin, B. (2011). Penelitian Kualitatif. Komunikasi, Ekonomi, Kebijakan Publik dan Ilmu Sosial Lainnya. Jakarta. Kencana Prenada Media

Schaduw, J. N. W. (2010). Pengelolaan Ekosistem Mangrove Berbasis Mitigasi (Kasus Pulau-Pulau Kecil Taman Nasional Bunaken). Bogor. Institit Pertanian Bogor.

Marjayanti, A. (2020). Analisis Potensi Objek Wisata Mempawah Mangrove Park di Desa Pasir Kabupaten Mempawah

Morisan. (2015). Metode Penelitian Survei. Jakarta. Prenadamedia

Muhamad. (2013). Kapasitas Daya Dukung Fisik dan Lingkungan Optimal sebagai Daya Dukung Kepariwisataan Alam Yogyakarta Utara setelah Pascaerupsi Merapi 2010. Jurnal Kawistara. 3 (II), 117-226.

Noor, Y. R., Khazali, M., Suryadiputra, I. N. N. (2006). Panduan Pengenalan Mangrove di Indonesia. Bogor.

Pemerintah Kabupaten Mempawah. (2016). Rancangan Rencana Induk Pariwisata Daerah Kabupaten Mempawah.

Rangkuti, F. (2018). Analisis SWOT Teknik Membedah Kasus Bisnis. Jakarta: PT. Gramedia Pustaka Utama.

Soekadijo, R. G. (2000). Anatomi Pariwisata: Memahami Pariwisata sebagai "SistemicLinkage". Jakarta. PT. Gramedia Pustaka Utama

Suryadana, M. L. (2013). Sosiologi Pariwisata: Kajian Kepariwisataan dalam Paradigma IntergratifTransformatif menuju Wisata Spiritual. Bandung: Humaniora.

Wibisono, M. S. (2004). Pengantar Ilmu Kelautan. Jakarta: PT Gasindo.

Wibowo, A. S. (2001). Pariwisata, Ekowisata dan Lingkungan. Jakarta

Yuniarti, E., Soekmadi, R., Arifin, H. S., Noorachmat, B. P. 2018. Analisis Potensi Ekowisata Heart of Borneo di Taman Nasional Betung Kerihun dan Danau Sentarum Kabupaten Kapuas Hulu. Jurnal Pengelolaan Sumberdaya Alam dan Lingkungan. 8 (I), 44-54 